$1-1-1910$

\title{
Construction of a Modern Poultry House and Report of Experiments in Hopper Feeding Laying Hens
}

Horace Atwood

Follow this and additional works at: https://researchrepository.wvu.edu/ wv_agricultural_and_forestry_experiment_station_bulletins

\section{Digital Commons Citation}

Atwood, Horace, "Construction of a Modern Poultry House and Report of Experiments in Hopper Feeding Laying Hens" (1910). West Virginia Agricultural and Forestry Experiment Station Bulletins. 130.

https://researchrepository.wvu.edu/wv_agricultural_and_forestry_experiment_station_bulletins/130 @ WVU. It has been accepted for inclusion in West Virginia Agricultural and Forestry Experiment Station Bulletins by an authorized administrator of The Research Repository @ WVU. For more information, please contact ian.harmon@mail.wvu.edu. 


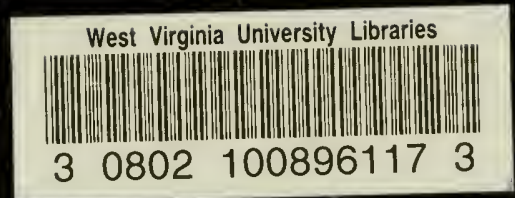


1.C- . IIIB

Tlitbraxy

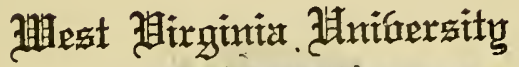
WEST UREA UiviveRSiY. 


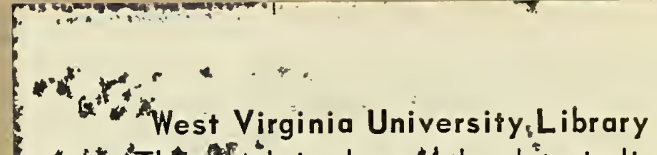

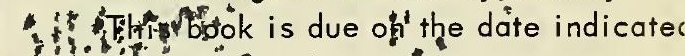

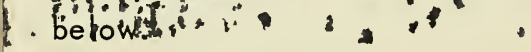

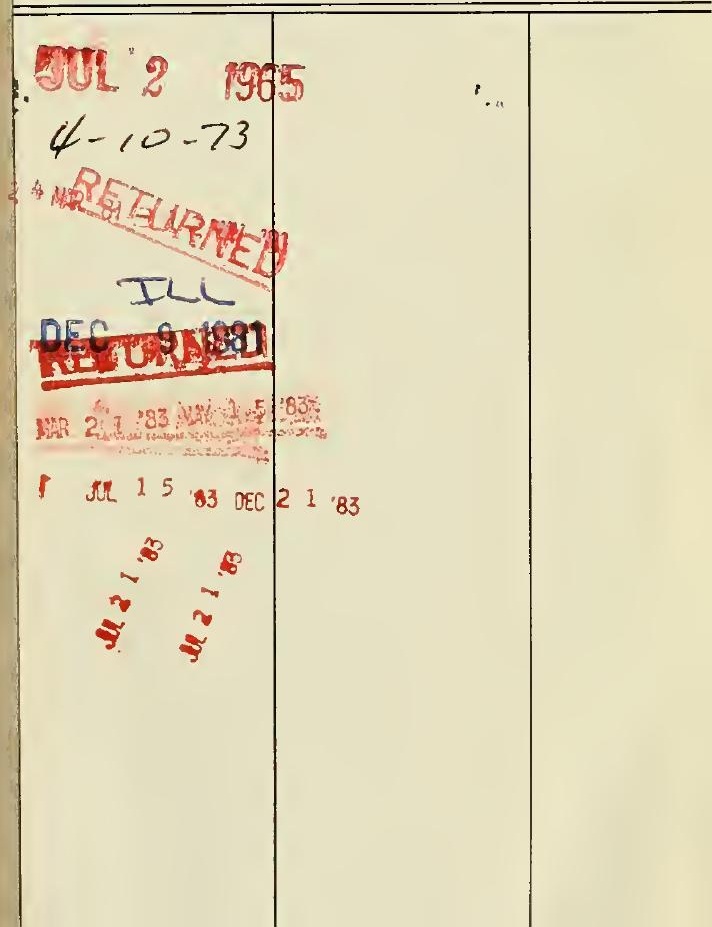





\section{WEST VIRGINIA UNIVERSITY \\ AGRICULTURAL EXPERIMENT STATION \\ MORGANTOWN, W. VA.}

Bulletin 130.

September， 1910

\section{Construction of a Modern Poultry House}

and Report of Experiments in Hopper Feeding Laying Hens

By Horace Atwood

[The Bulletins and Reports of this Station will be mailed free to any citizen of West Virginia upon written application. Address Director of Agricultural Experiment Station, Morgantown, W. Va.] 
Hon. M. P. Shawkey ................. Charleston, W. Va. Hon. J. B. Finley................. Parkersburg, W. Va. Hon. George S. Laidley................ Charleston, W. Va. Hon. G. A. NoRTHсотт................ Huntington, W. Va. Hon. M. C. Lough..................... Fairmont, W. Va.

President of the Board of Regents.............. P. SHAwkeY President of the University................ D. B. Purinton Treasurer........................ Thomas E. Hodges

\section{STATE BOARD OF CONTROL.}

Hon. JaMes S. LAKin.................. Charleston, W. Va. Hon. John A. Sheppard................ Charleston, W. Va. Hon. Thoms E. Hodges................. Charleston, W. Va.

\section{STATION STAFF.}

James H. Stewart, A. M......... Director and Agrieulturist Bert H. Hite, M. S............ Vice Director and Chemist ${ }^{*}$ W. M. Munson, Ph. D. . . . . . . . . . . . Horticulturist W. E. Rumsey B,. S. AGr................... Entomologist

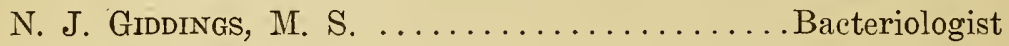
Horace Atwood, M. S. Agr. ........... Assistant Agriculturist Fred E. Brooks.................. Associate Entomologist Frank B. Kunst, A. B................ Assistant Chemist Chas. E. Wenkuex, Jr................... Assistant Chemist J. H. Berghuis Krak.................. Assistant Chemist

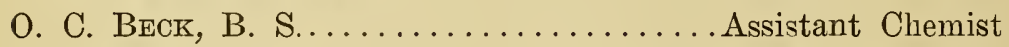
A. L. DACY, B. Sc................ Assistant Horticulturist Charles M. Gifford, B. S............ Assistant Bacteriologist W. J. White......................... Bookkeep?r M. A. Stewart . . . . . . . . . . . . . . . Librarian Alice Engle........................................

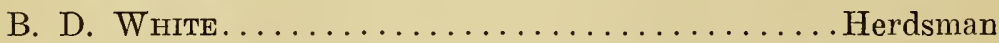
Theо. F. Iмвасн...................... Greenhouseman *Deceased. 
Digitized by the Internet Archive in 2010 with funding from

Lyrasis Members and Sloan Foundation 


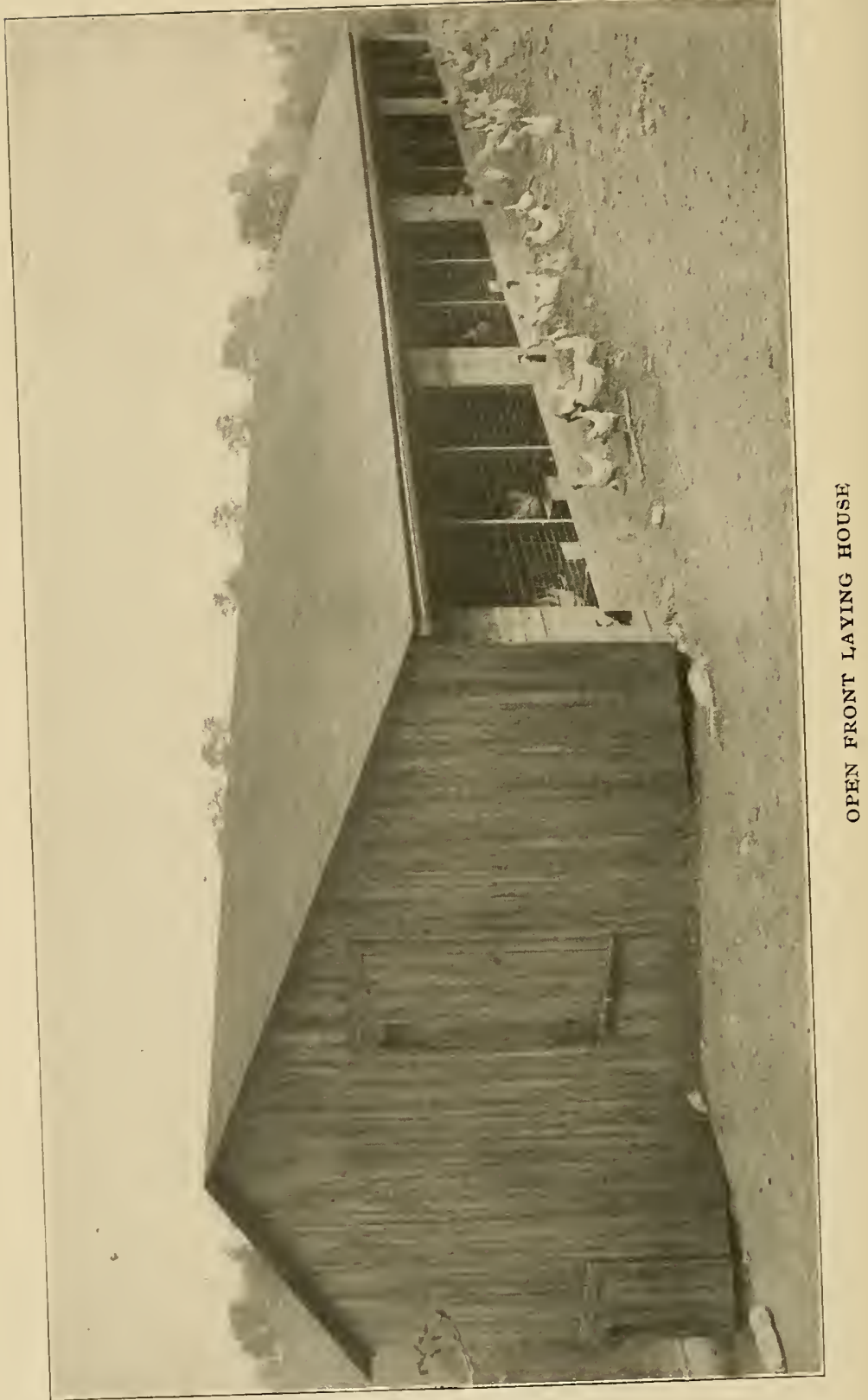




\section{Experiments in Hopper Feeding Laying Hens}

In the production of eggs the main items of expense are for the food required by the fowls; for labor to eare for them; for repairs to the buildings and equipment; and for systematieally replacing each year the older individuals with younger and more productive hirds. The amount and the east of focd required by a fowl in the course of a year has been set forth in former bulletins of this Station.

The cost of labor to eare for a fowl for a year depends upon. several faetors among which may be mentioned the number of forwls kept, the manner in which they are housed, fed and watered, and the facilities for eleaning and keeping the houses in a sanitary condition, and free from lice and mites. As no two poultry houses are the same in all respects it is quite probable that the labor cost of earing for forvls varies widely in slifferent sections of the eountry and under different conditions.

. In an address delivered before the American Poultry Association it was stated that on a certain poultry plant in Maine where two thousand hens are kept in a long laying house the labor cost is thirty-six cents per hen per year. This tid not cover the cost of removing the soiled litter, and replacing it with straw or other seratehing material.

In this particular instance the eost of labor per fowl, rer year, was apparently about one-third as much as the cost of food. On many other egg farms where the arrangements are not so eonvenient as in the case mentioned it is entirely probable that the lahor cost for caring for forrls may amount to one-half as much as the cost for food or perhaps even more.

In practice it is just as important to economize in respect to the cost of labor" as it is to inerease the egg yield hy skillful feeding or breeding, as in both eases the object is to lower the eost of production. 
Is there any way of feeding fowls which requires littlc time and attention and yet which gives good results with respect to egg yield?

\section{HOPPER FEEDING.}

On many farms it has been the custom in the past to feed once per day a mash composed of ground grain, beef scrap, etc., moistened with water. Moistening the ground feed and placing it in troughs for the fowls requires considerable time. Experience and good judgment are also required in order to feed just the proper amount. If too much mash is fed the excess is usually wasted, and if not enough is supplied the egg production is restricted to that extent.

In the hopper system of feeding, the grain or dry mash is placed in suitable receptacles so that the fowls can help themselves at will. This materially reduces the cost of labor in feeding the fowls, but do they lay as well? The experiment described below has been performed for the purpose of beginning the study of this subject.

The experiment began December 8th, 1905, with four lots of fowls each consisting of twenty single comb White Leghorn pullets. On January 17, 1906, another pen of twenty White Leghorn pullets was added to the test and the record of this pen also is given. The pullets added to the test in January were hatched later in the season than those in the other four pens and were practically of the same age and weight when added to the test as the other pullets were at the beginning, and it is believed that the results derived from all five pens are to a certain extent comparable. The test was continued for one year.

The method of feeding each pen was as follows:

Pen 1. This lot of fowls was fed shelled corn, beef scrap, and wheat bran, in hoppers constructed so that there was a supply of these feeding stuffs constantly before them. The general health of these fowls was apparently good, although the mortality was heavy, four dying in the course of the year. Those which died were fat and heavy and probably the cause of death was enlargement of the liver. 
Pen 2. This pen was hopper fed with corn, beef scrap, and a mixture of equal parts by weight of corn meal, wheat bran, and ground oats. For the first month the corn, beef serap and ground feed was supplied ad libitum, but as the egg production was very unsatisfactory with a supply of corn constantly before the fowls, the practice was adopted for the remainder of the year of closing the corn orifice early in the morning and opening it again at night when picking up eggs. The fowls in this pen, then, had access to beef scrap and ground grain during the day, and to shelled corn for a short time at night and morning. Three hens died in this pen, one from prolapsus of the oviduct, one was crop bound and the other died from some undetermined cause.

Pen 3. This pen was hopper-fed with (1) a mixture of equal parts by weight of corn, wheat, and oats; (2) beef scrap; and (3) a mixture of equal parts by weight of corn meal, ground oats and wheat bran. As the corn, wheat and oats were mixed together it was thought that it would be possible to make the fowls eat the oats as well as the wheat and corn. It was found in practice, however, that after the oats had accumulted to a certain extent in the trough of the self-feeder they were thrown out by the fowls and some unavoidably wasted, thus making the recorded food consumption for this pen abnormally high. There was no mortality.

Pen 4. This pen of fowls was fed a moistened mash in the morning consisting of a mixture of corn meal, wheat bran, ground oats and beef scrap. Toward evening a mixture of whole grain was scattered in the litter covering the floor of the house. There were no deaths.

Pen 9. This flock was hopper fed with a mixture of equal parts by weight of corn meal, wheat bran and ground oats. In another compartment of the hopper beef scrap was supplied. Once per day a mixture of whole grain was seattered about in the litter so as to induce the hens to take exercise. Two hens died, the cause of death was not determined.

The fowls in this test were confined to the houses and runs described in former bulletins, the houses being about ten feet 
wide and twenty feet long and the runs about thirty feet wide by a hundred feet long. No green food was supplied them in winter, but in summer a fair quantity of green stuff grew in the runs but the supply toward fall became limited. In all cases the food was weighed out carefully in bulk for rach $p$ ('n by the Assistant Agriculturist but the actual feeding was intrusted to a farm laborer.

The following table shows the average weight of the hens at the beginning, and end of the test; on May 21st; and $\mathrm{cn}$ August 25th.

TABLE SHOWING WEIGHT OF FOWLS.

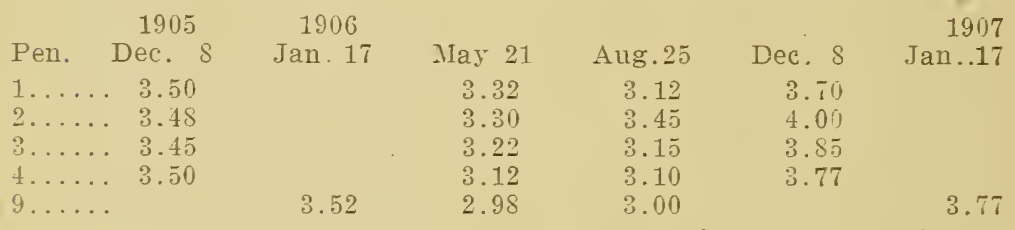

During May and August the forls were not so heavy as at the beginning of the test. At the close of the year, however, all of the fowls were somerhat heavier than at the beginning.

The following table shows the amount and lind of food consumed by the various pens of fowls during the year:

\section{POUNDS FOOD CONSUIIED.}

\begin{tabular}{|c|c|c|c|c|c|c|c|c|}
\hline Pen & Corn & Wheat & Oats & $\begin{array}{l}\text { Corn } \\
\text { Meal }\end{array}$ & $\begin{array}{l}\text { Wheat } \\
\text { Bran }\end{array}$ & $\begin{array}{l}\text { Ground } \\
\text { Oats }\end{array}$ & $\begin{array}{l}\text { Beef } \\
\text { Scrap }\end{array}$ & Total \\
\hline $1 .$. & 1024.3 & & & & 115 & & 50 & 1189.3 \\
\hline 2. & S6อ & & & 142 & 142 & 142 & 91 & 1382 \\
\hline 3. & 385 & 375 & 375 & 102 & 102 & 102 & 79 & 1520 \\
\hline & 288 & 288 & 288 & 145 & 145 & 145 & 90 & 1389 \\
\hline $9 \ldots \ldots$ & 276 & 276 & 258 & 142 & 148 & 144 & 148 & 1392 \\
\hline
\end{tabular}

The table shows the pens $2,+\frac{1}{x}$ and 9 consumed almost exactly the same amount of food, or in round numbers practically seventy pounds per forwl. The food consumption of pen 1 was 
slightly less than in the case of pens 2, 4 and 9, and pen 3 stands higher, probably due to wastage as already noted.

The following schedule of prices has been used in calculating the cost of feed consumed by the fowls. These prices represent as accurately as conld be determined the average retail prices which prevailed in MTorgantown during the year covered by the test.

Corn $\$ 1.08$ per hundred.

Wheat $\$ 1.50$ per hundred.

Oats $\$ 1.40$ per hundred.

Corn Meal $\$ 1.25$ per hundred.

Wheat bran $\$ 1.25$ per hundred.

Ground oats $\$ 1.50$ per hundred.

Beef serap $\$ 2.25$ per hundred.

The following table gires the eost of the food consumed by the experimental pens during the year.

\section{COST OF FOOD.}

$\begin{array}{crrrrrrrr}\text { Pen } & \text { Corn } & \text { Wheat } & \text { Oats } & \begin{array}{c}\text { Corn } \\ \text { Meal }\end{array} & \begin{array}{c}\text { Wheat } \\ \text { Bran }\end{array} & \begin{array}{c}\text { Ground } \\ \text { Oats }\end{array} & \begin{array}{c}\text { Beef } \\ \text { Scrap }\end{array} & \text { Total } \\ 1 \ldots \ldots & \$ 11.06 & & & & 1.44 & & 1.12 & 13.62 \\ 2 \ldots \ldots & 9.34 & & & 1.77 & 1.77 & 2.13 & 2.04 & 17.05 \\ 3 \ldots \ldots & 4.15 & 5.62 & 5.25 & 1.27 & 1.27 & 1.53 & 1.78 & 20.87 \\ 4 \ldots \ldots & 3.11 & 4.32 & 4.03 & 1.81 & 1.81 & 2.17 & 2.02 & 19.27 \\ 9 \ldots \ldots & 2.98 & 4.14 & 3.61 & 1.77 & 1.85 & 2.16 & 3.33 & 19.84\end{array}$

The table shows that pen 1 , fed principally upon corn, was fed for the least money. Next in order stands pen 2, followed in turn by pens 4, 9 and 3. The total eost of food for the year for the hundred fowls which were in this test was $\$ 90.65$, or slightly more than ninety cents per fowl. 
The following table shows the egg production by months for the different lots of fowls:

\begin{tabular}{|c|c|c|c|c|c|}
\hline 1905 & Pen 1 & Pen 2 & Pen 3 & Pen 4 & Pen 9 \\
\hline $\begin{array}{l}\text { Dec. } \\
1906\end{array}$ & $\ldots \ldots \ldots \ldots \ldots \quad 71$ & 46 & 80 & 118 & (Jan. 17) \\
\hline Jan. & $\ldots \ldots \ldots \ldots \ldots, \quad 61$ & 138 & 37 & 140 & 69 \\
\hline Feb. & $\ldots \ldots \ldots \ldots \ldots 152$ & 199 & 139 & 149 & 232 \\
\hline Mar. & $\ldots \ldots \ldots \ldots \ldots 288$ & 398 & 357 & 390 & 406 \\
\hline Apr. & $\ldots \ldots \ldots \ldots \ldots 258$ & 357 & 300 & 334 & 332 \\
\hline May & .......... 202 & 295 & 300 & 300 & 323 \\
\hline June & ........... 205 & 299 & 286 & 287 & 299 \\
\hline July & .......... 169 & 278 & 238 & 253 & 323 \\
\hline Aug. & $\ldots \ldots \ldots \ldots \ldots 141$ & 227 & 220 & 195 & 241 \\
\hline Sept. & $\ldots \ldots \ldots \ldots \ldots \quad 36$ & 99 & 86 & 57 & 172 \\
\hline Oct. & $\ldots \ldots \ldots \ldots \ldots$ & 23 & 20 & 21 & 52 \\
\hline Nov. & $\ldots \ldots \ldots \ldots \ldots$ & 32 & 13 & 68 & $\ldots$ \\
\hline $\begin{array}{l}\text { Dec. } \\
1907\end{array}$ & $\ldots \ldots \ldots \ldots \ldots$ & 16 & 24 & 21 & 27 \\
\hline Jan. & $17 \ldots \ldots \ldots \ldots \ldots$ & $\cdots$ & $\cdots$ & $\cdots$ & 19 \\
\hline Total & $\ldots \ldots \ldots \ldots \ldots 1628$ & 2407 & 2100 & 2333 & 2495 \\
\hline
\end{tabular}

The egg production was not especially heavy with any of the pens of fowls. The best record was made by pen 9 , which was hopper fed with mash and beef scrap, and with whole grain once per day scattered in deep litter. Next in order stands pen 2, which had access to corn in a hopper for a short time in the morning and evening. Materially behind all of the other pens, and with a remarkably low egg record, is pen 1 , which received corn, beef scrap and wheat bran ad libitum.

The following table shows the average food cost of the eggs per dozen and the cost of food per hen per year.

\begin{tabular}{|c|c|c|}
\hline Pen 1 & $\begin{array}{l}\text { Cost of eggs. } \\
10 \quad \text { cts. per doz. }\end{array}$ & $\begin{array}{c}\text { Cost of food per hen per year. } \\
68 \mathrm{cts} \text {. }\end{array}$ \\
\hline Pen 2 & $8.5 \mathrm{cts}$ per doz. & $85 \mathrm{cts}$. \\
\hline en 3 & $11.9 \mathrm{cts}$ per doz. & $104 \mathrm{cts}$. \\
\hline en 4 & $9.9 \mathrm{cts}$ per doz. & 96 cts. \\
\hline en 9 & 9.5 cts per doz. & $99 \mathrm{cts}$. \\
\hline
\end{tabular}





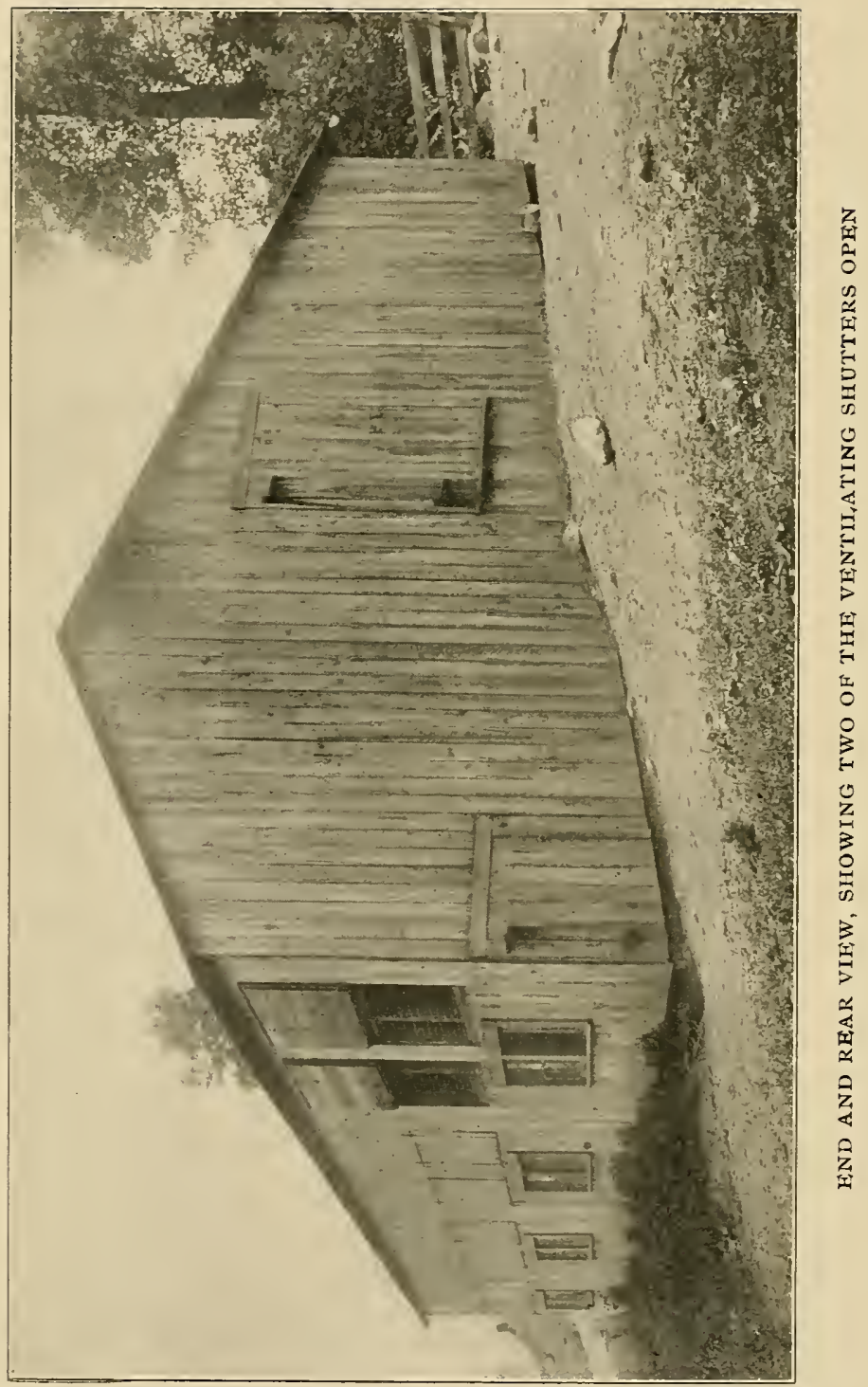


'The table shows that the food eost of the'eggs prorluced by the different pens during the year varied from 8.5 cents 1011.9 eents per dozen. Pen 2 leads in respect to low eost of ergs while pen 1 leads in respeet to the cheapness of the ration. The hopper fed pens, 2 and 9, produced eggs having a lower food cost, and those laid by pen 1 cost only slightly more, than those laid by pen 4 which reeeived moistened mash.

\section{SUMMARY.}

1st. In a year's test with five pens of fowls the cost of food varied from eighty-five cents to one dollar and four cents per fowl per year, and averaged ninety cents per fowl for the one hundred fowls in the experiment.

2nd. The eg'g production varied from 81.4 eggs per hen in the ease of pen 1 , fed principally upon corn, to $12 \frac{1}{2} .7$ in the ease of pen 9 , which received whole grain once per day, scattercd in litter, and dry mash and beef scrap ad libitum in a hopper.

3rd. The food cost of the eggs during the year varied from 8.5 cents to 11.9 eents per dozen.

4th. Two pens, hopper fed, produeed eggs having a lower food cost than the pen which reeeived moistened mash, and in this test there was apparently no benefit from the extra labol involved in moistening the mash.

\section{AN OPEN FRONT LAYTNG HOLSE.}

In Bulletin No. 115 of this Station is given a description, together with working drawings of the curtain front laying house which was erected on the Station farm some years ago. This house has continued to give satisfaction in respest to the comfort and health of the fowls. It has been found. however, that the double wall on the north side of the house is an excellent harbor for rats and this method of construetion should be avoided in building poultry houses. Recently another house has been erected of a different type, and as it also seems to be rell 
adapted to West Virginia conditions a description of it should be of interest to West Virginia poultrymen.

The honse under discussion is of the open front or Tolman style, and is characterized by having the front completely open or covered only with wire netting in order to keep out stray animals or vermin. The house is twenty-four feet wide and sixty-four feet long and is divided by solid board partitions into four sections, or rooms, each sixteen feet wide and twenty-four feet long. The louse is five feet high in front and six above the basement or scratching room in the rear. The roof is of unequal span, the peak being located two thirds of the distance from the front to the rear, and having an elevation above the floor of ten and one-half feet.

Being located on sloping ground, the house was provided with a scratching shed underneath. This portion is about four feet high with a dirt floor and the fowls gain access to it through trap doors placed in each section. This provides a place for the fowls to dust themselves and exercise in winter and is a very desirable feature.

The perches are on a level with the front opening. In winter when the fowls have gone to roost the warm air resulting from their presence tends to collect in the upper portion of the house maintaining a comfortable temperature even in severe weather. Last winter with its zero temperatures the combs of S. C. White Leghorn hens were not frozen even when the front of the house remained constantly open. In poultry houses having a shed roof the warm air constantly flows away from the fowls, when they are on the perches, thus making the shel roof. type of house somewhat colder for the fowls at night.

In order to keep the house cool during the warm season two doors are provided in the rear wall of each section of the building, opening underneath the nest boxes. When these doors are open, as in summer, the wind has unobstructed passage through the house and the fowls when on the perehes remain comfortable even on very sultry nights.

This house has been in use for a year and seems to be well 


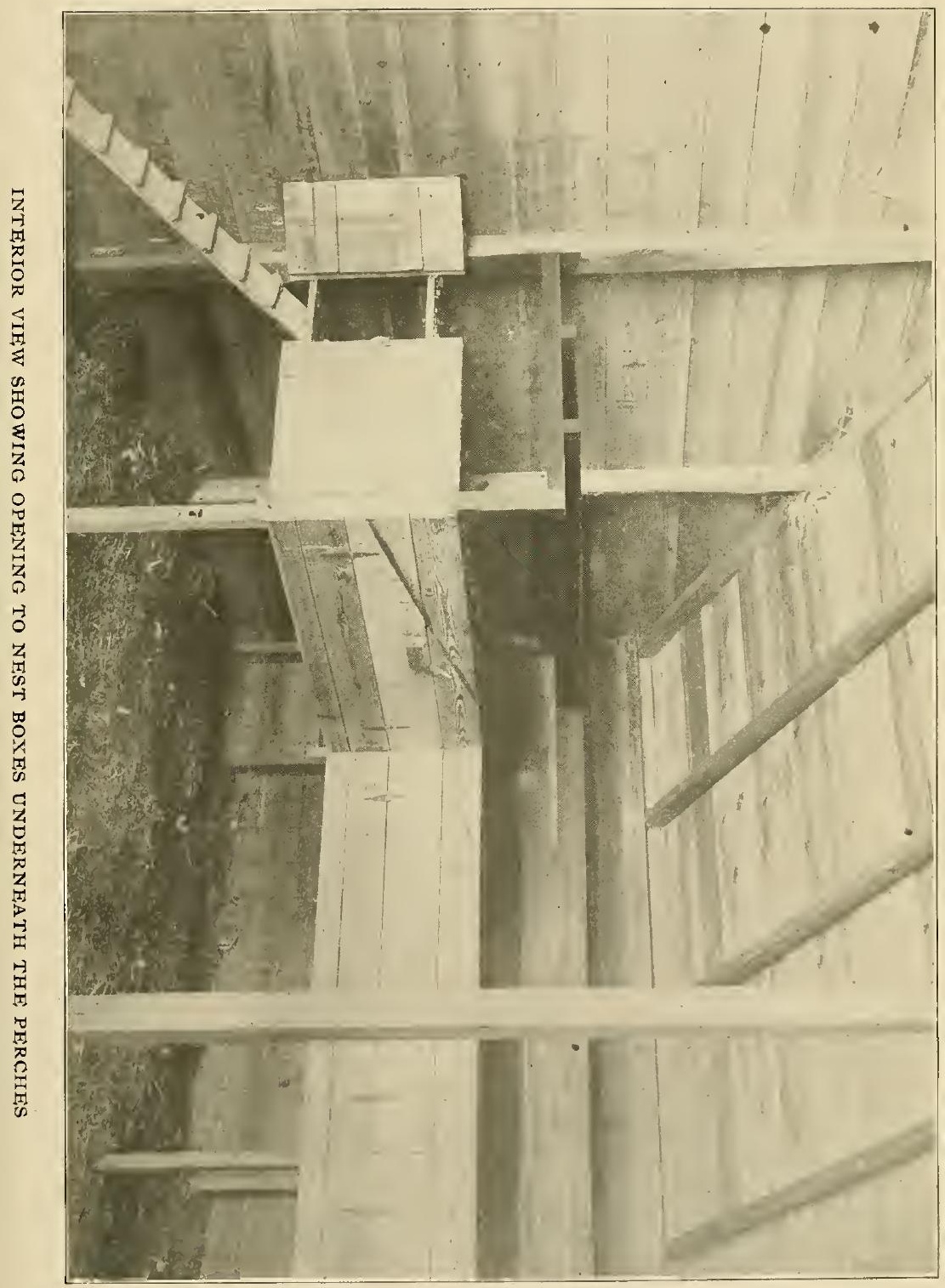



adapted to West Virginia conditions. It should face the south or southeast, and if a wind break is provided opposite the open side so much the better.

One of the advantages of this house is that the fowls always have plenty of fresh air and consequently remain healthier than where they are compelled to breathe impure air too often found in poultry houses. The free circulation of air too prevents any condensation of moisture on the walls of the building during frosty weather, and the litter on the floor constantly remains crisp and dry. Fowls remain healthier in a cold dry house than in a warm damp one.

The house was built by contract and cost $\$ 450$, complete. Four hundred Leghorns can be housed comfortably in it.

The cuts drawn to scale show the details of construction, and the bill of material for one section of the house including both sides is appended hereto. If two or more sections are constructed multiply the amount of material required for one section by the number of sections, and deduct the amount of ceiling to board up one side.

\section{BILL OF MATERIALS FOR MODEL POULTRY HOUSE. ONE SECTION ONLY, $24^{\prime} \times 16^{\prime}$.}

6 pes. posts, $6^{\prime \prime} \times 2^{\prime} 6^{\prime \prime}$ locust.

3 pes. posts, $6^{\prime \prime} \times 3^{\prime} 6^{\prime \prime}$ locust.

3 pes. posts, $6^{\prime \prime} \times t^{\prime} 6^{\prime \prime}$ locust.

11 pes. joist, $2^{\prime \prime} \times 8^{\prime \prime}-16^{\prime} 0^{\prime \prime}$ long, hemlock.

11 pes. joist, $2^{\prime \prime} \times 8^{\prime \prime}-8^{\prime} 0^{\prime \prime}$ long, hemlock.

9 pes. rills, girders, etc., $2^{\prime \prime} \times 8^{\prime \prime}-16^{\prime} 0^{\prime \prime}$ long, hemlock.

14 pes. plates and joist bearers, $2^{\prime \prime} \times 4^{\prime \prime}-16^{\prime} 0^{\prime \prime}$ long, hemlock.

40 pcs. studding, etc., $2^{\prime \prime} \times 4^{\prime \prime}-12^{\prime} 0^{\prime \prime}$ long, hemlock.

9 pes. rafters, $2^{\prime \prime} \times 6^{\prime \prime}-18^{\prime} 0^{\prime \prime}$ long, hemlock.

9 pes. rafters, $2^{\prime \prime} \times 4^{\prime \prime}-10^{\prime} 0^{\prime \prime}$ long, hemlock.

50 ft. b. m. patent siding, $5^{\prime \prime}$ face, poplar.

700 ft. b. m. shiplap, $5^{\prime \prime}$ face, poplar. 
600 ft. b. m. roof sheathing, 4" common No. 2 y. p. flooring. 350 ft. b. m. double surfaced y. p. ceiling, 7/8" $\mathrm{x} 4^{\prime \prime}$ No. 2 com. 600 ft. b. m. flooring, matched y. p. 3r/2" face, No. 2.

75 ft. b. m. ceiling, 5/s" $x 3^{\prime \prime}$ matched and bearded, y. p. No. 2.

2 pes. $7 / 8 " \times 10^{\prime \prime}-16^{\prime} 0^{\prime \prime}$ long, S-4-S, poplar, feed trough.

1 pes. $7 / 8 " x 4^{\prime \prime}-16^{\prime} 0^{\prime \prime}$ long, S-4-S, poplar, feed trough.

1 pes. $7 / 8^{\prime \prime} \times 7^{\prime \prime}-16^{\prime} 0^{\prime \prime}$ long, S-4-S,poplar, nests.

4 pes. $7 / 8$ " $\times 55^{\prime \prime}-10^{\prime} 0^{\prime \prime}$ long, S-4-S,poplar, nests.

1 pes. $7 / 8 " x 8^{\prime \prime}-12^{\prime} 0^{\prime \prime}$ long, S-4-S, poplar, gangs.

2 pes. $7 / 8^{\prime \prime} \times 5^{\prime \prime}-12^{\prime} 0^{\prime \prime}$ long, S-4-S, poplar, gangs.

1 door frame, $2^{\prime} 10^{\prime \prime} \times 6^{\prime} 0^{\prime \prime}-1 / 2 " \times 13 / 4$ " rebate strip, poplar.

1 door frame, $2^{\prime} 8^{\prime \prime} \mathrm{x} 4^{\prime} 0^{\prime \prime}-\mathrm{I} / \mathrm{2}^{\prime \prime} \mathrm{x} 13 / 4^{\prime \prime}$ rebate strip, poplar.

1 door frame, $2^{\prime} 11 \frac{1}{2}{ }^{\prime \prime} \mathrm{x} 6^{\prime} 5^{\prime \prime}$-fitted with $1 \frac{1}{2} 2^{\prime \prime} \mathrm{x} 1 \frac{1}{2} 2^{\prime \prime}$ hinge strip for double acting door, poplar.

2 doors, $2^{\prime} \cdot 10^{\prime \prime} \times 6^{\prime} 0^{\prime \prime}-7 / 8$ double surfaced, matched and beaded batten doors with $7 / 8$ " $\times 4^{\prime \prime}$ battens, poplar.

1 door, 2' 8'x4' $0^{\prime \prime}-7 / s^{\prime \prime}$ double surfaced, matched and beaded batten door with $7 / 8$ " $x 4^{\prime \prime}$ battens, poplar.

1 mullion window frame, 2 single sash, 6 lt. $10^{\prime \prime} \times 12^{\prime \prime}$, poplar.

2 sash, 13/8"-6 lt. 10"x12", glazed S. S. A. glass.

5 squares composition tarred felt roofing, 2 ply, first quality.

2 squares tarred building felt, 2 ply.

14 lin, ft. mesh wire, $3^{\prime \prime}$ sq. mesh. 50" wide, No. 20. wire. 14 lin, ft. mesh wire, $3^{\prime \prime}$ s'q. mesh. $32^{\prime \prime}$ wide, No. 20. wire. 


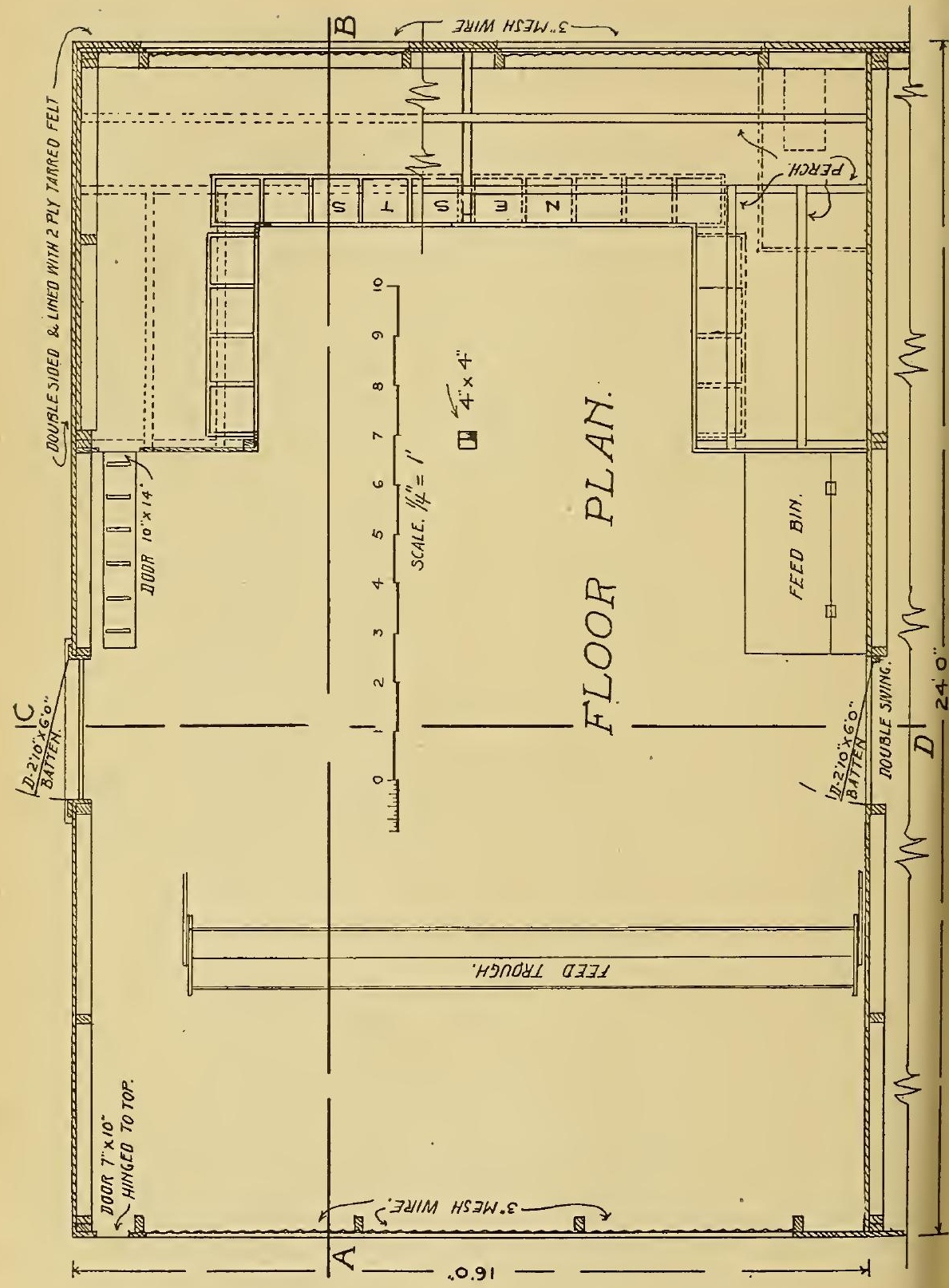




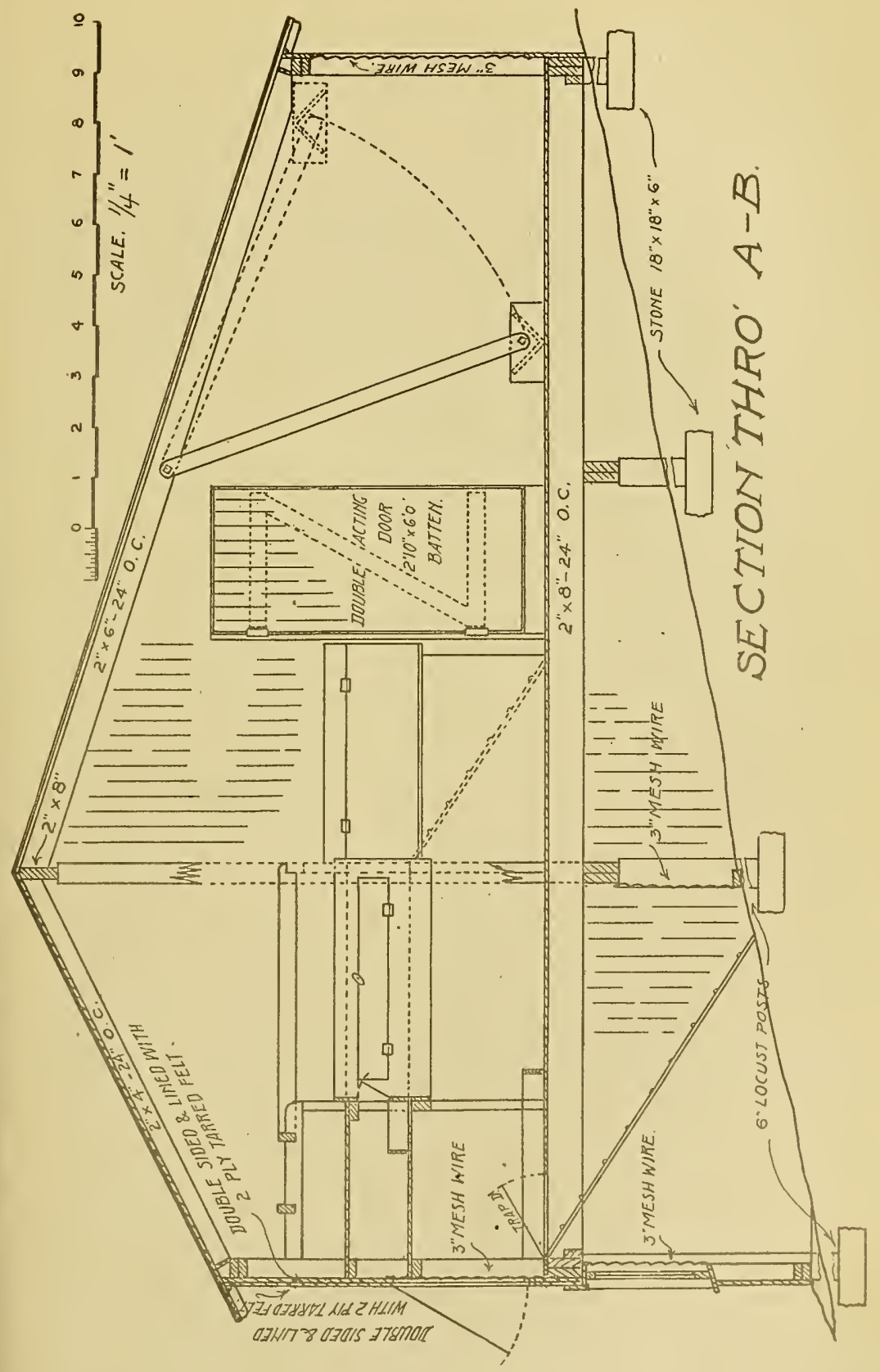




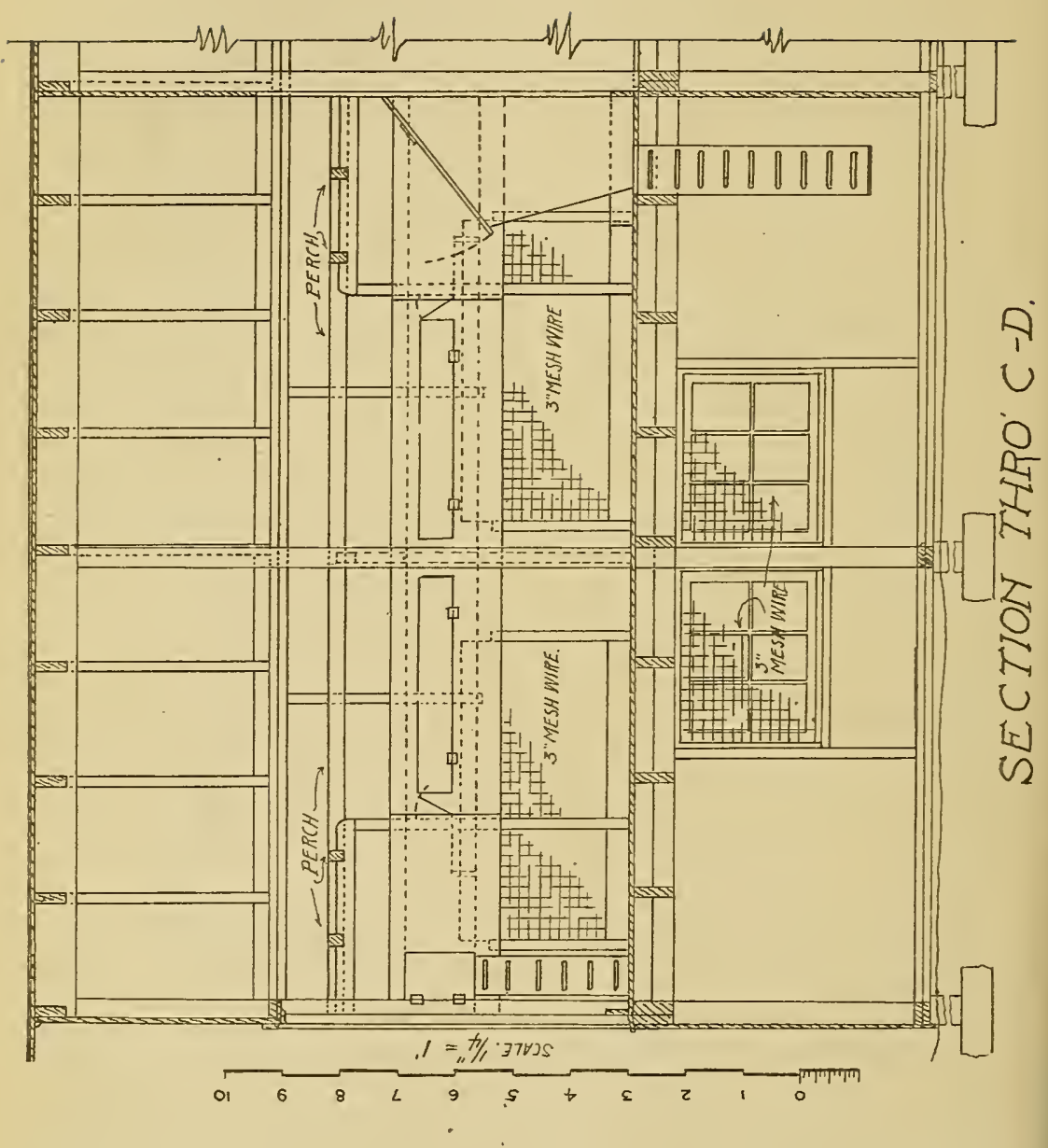




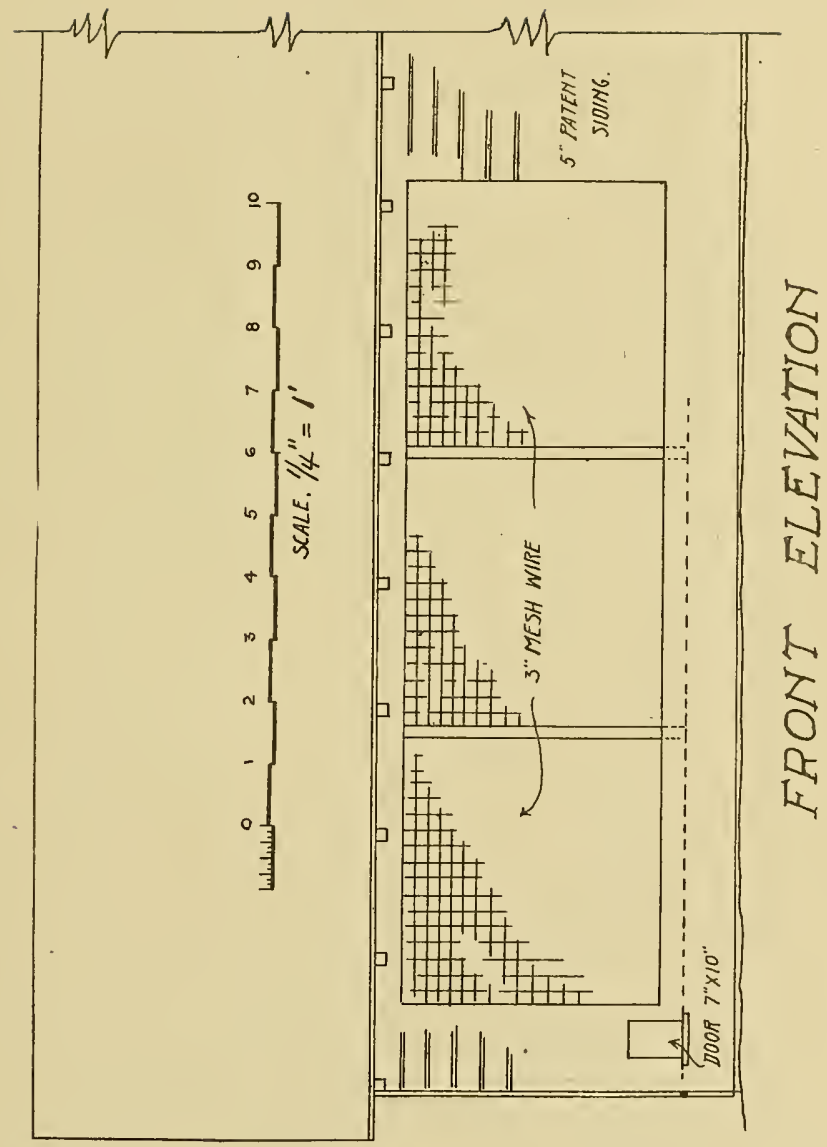




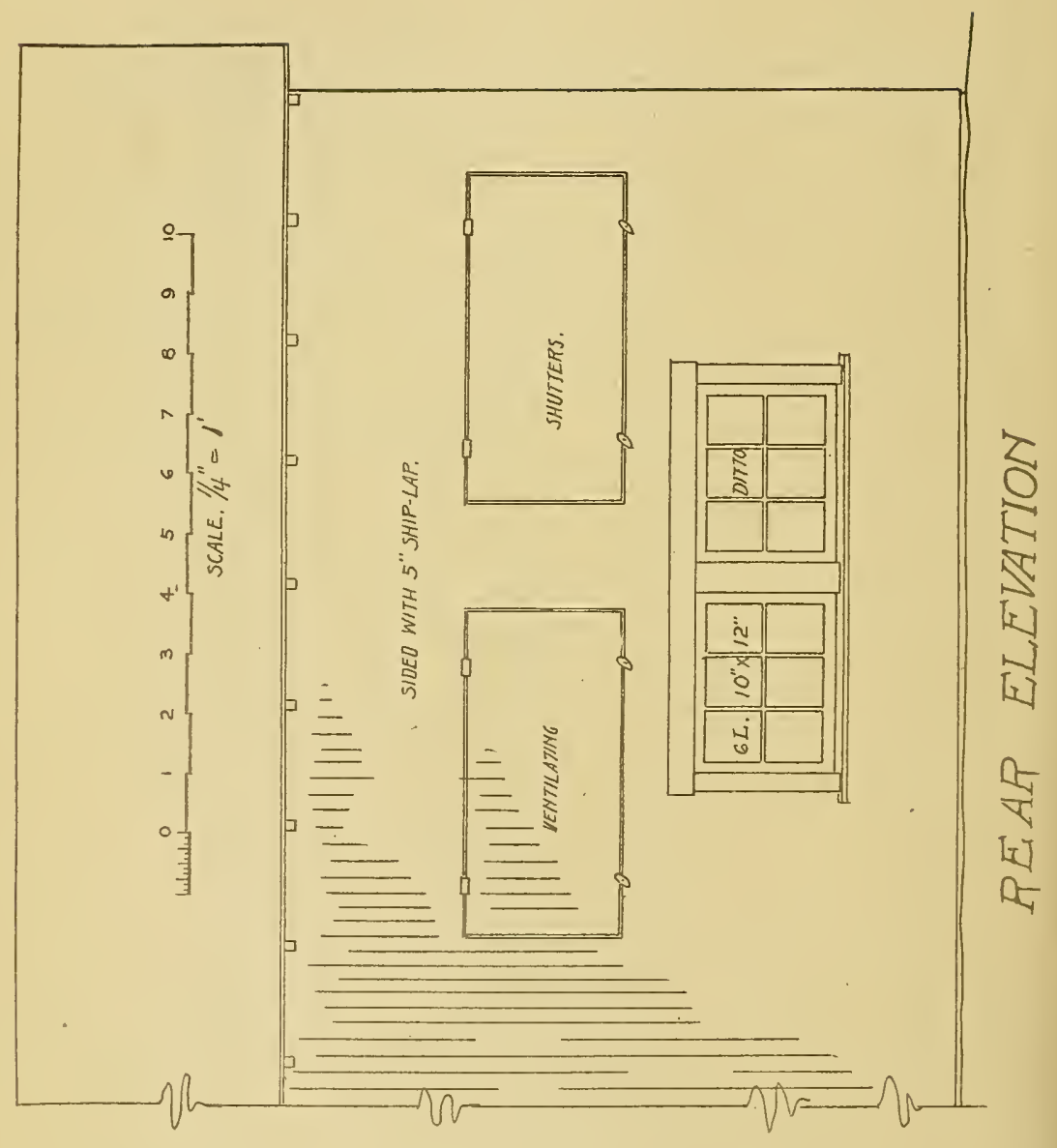




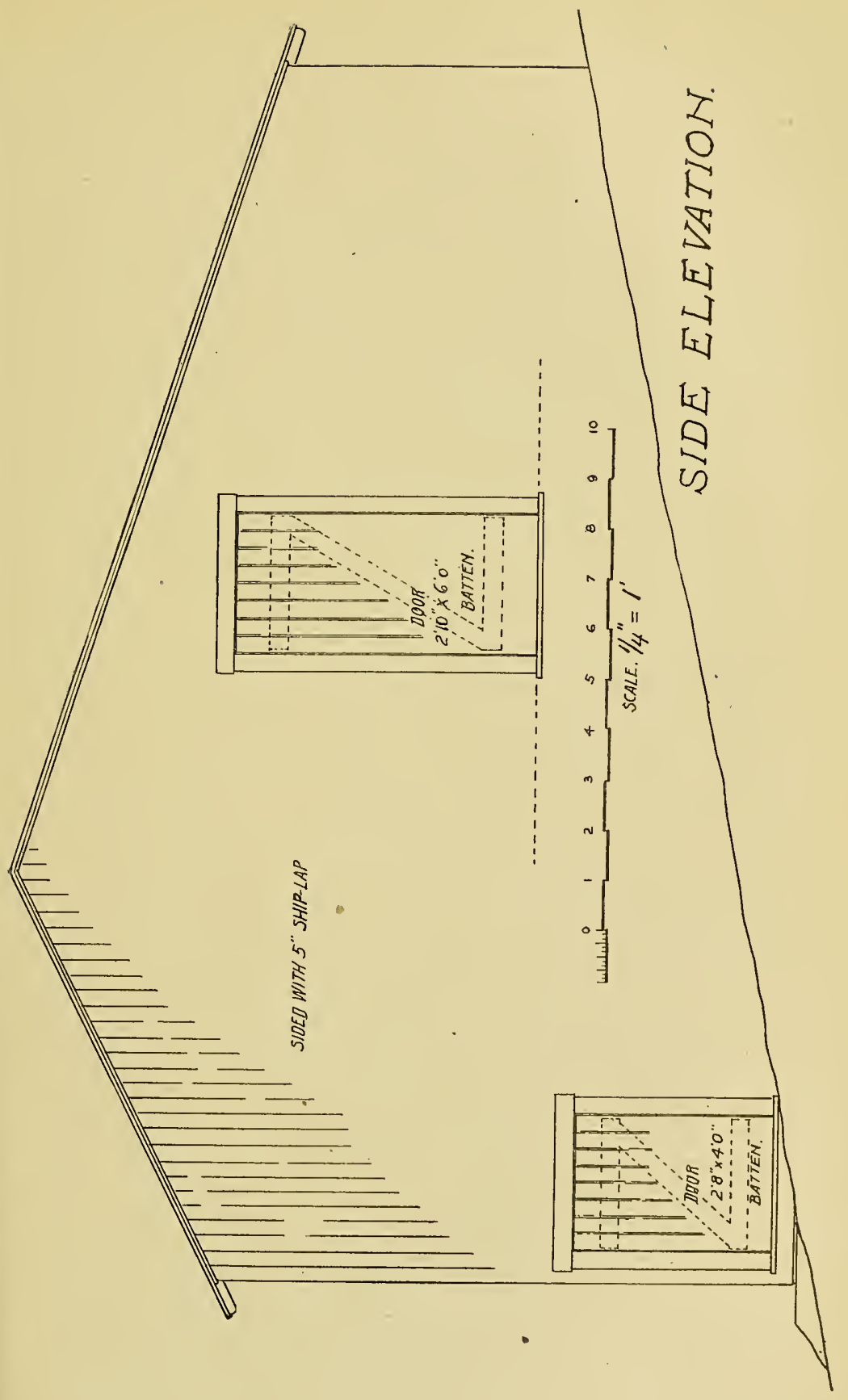





